\title{
The Influence of Dyslexia Candidate Genes on Reading Skill in Old Age
}

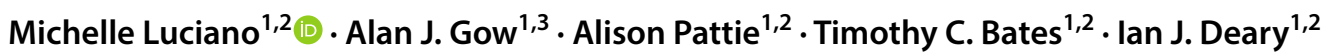

Received: 23 February 2018 / Accepted: 23 June 2018 / Published online: 29 June 2018

(c) The Author(s) 2018

\begin{abstract}
A number of candidate genes for reading and language impairment have been replicated, primarily in samples of children with developmental disability or delay, although these genes are also supported in adolescent population samples. The present study used a systematic approach to test 14 of these candidate genes for association with reading assessed in late adulthood (two cohorts with mean ages of 70 and 79 years). Gene-sets (14 candidates, axon-guidance and neuron migration pathways) and individual SNPs within each gene of interest were tested for association using imputed data referenced to the 1000 genomes European panel. Using the results from the genome-wide association (GWA) meta-analysis of the two cohorts $(\mathrm{N}=1217)$, a competitive gene-set analysis showed that the candidate gene-set was associated with the reading index $(\mathrm{p}=.016)$ at a family wise error rate corrected significance level. Neither axon guidance nor neuron migration pathways were significant. Whereas individual SNP associations within CYP19A1, DYX1C1, CNTNAP2 and DIP2A genes (p <.05) did not reach corrected significance their allelic effects were in the same direction as past available reports. These results suggest that reading skill in normal adults shares the same genetic substrate as reading in adolescents, and clinically disordered reading, and highlights the utility of adult samples to increase sample sizes in the genetic study of developmental disorders.
\end{abstract}

Keywords Dyslexia $\cdot$ Neuronal migration $\cdot$ Axon guidance $\cdot$ Reading ability $\cdot$ Lothian birth cohort

\section{Introduction}

Reading performance is highly heritable (Bates et al. 2004; Hayiou-Thomas et al. 2010), making the genetic study of this skill important for understanding the causes of disorders in these abilities (Fisher and DeFries 2002). A number of candidate genes influencing reading and language impairment have been discovered (e.g., Francks et al. 2004; Meng et al. 2005a, b) and have replicated in population samples

Edited by Chandra Reynolds.

Electronic supplementary material The online version of this article (https://doi.org/10.1007/s10519-018-9913-3) contains supplementary material, which is available to authorized users.

Michelle Luciano

michelle.luciano@ed.ac.uk

1 Centre for Cognitive Ageing and Cognitive Epidemiology, University of Edinburgh, Edinburgh, Scotland, UK

2 Department of Psychology, University of Edinburgh, 7 George Square, Edinburgh EH9 8JZ, Scotland, UK

3 Department of Psychology, Heriot Watt University, Edinburgh EH14 4AS, Scotland, UK of adolescents and young adults (Bates et al. 2010; Luciano et al. 2007; Scerri et al. 2011). However, it is known that larger samples are required to successfully search the genome for complex trait variants (Price et al. 2015) if desired outcomes such as substantive polygenic risk scores (Luciano et al. 2017) and new gene discoveries important for understanding biological pathways (Wang et al. 2010) are to be made. Child samples are, however, typically not on the scale required. One possible route forward in the genetics of reading disorder would be to utilise samples of older adults to facilitate large GWA studies which could inform developmental disorders. A barrier to large-scale investment in this approach is that it is currently unknown whether reading disorder in adults follows the same genetic pattern as in children, or even if genes associated with reading replicate in older adults, with many years of practice at the skill. To validate this approach, here, we tested association between 14 candidate genes-implicated in reading impairmentand reading ability in two elderly cohorts.

There are no longitudinal studies specifically on reading skill spanning childhood past young adulthood, but variation in normal cognitive ability has been shown to be stable over the life course (Deary et al. 2000). Further, measures of 
reading comprehension taken in high-school have been shown to explain $\sim 80 \%$ of variance in adult reading, measured 21 or 26 years later (Smith 1993). This suggests that correlated measures of reading skill would be similarly predictive over time. Children with reading impairment can improve with intervention (Foorman et al. 2003), and whereas strategies to compensate for specific weaknesses can develop, reading impairment does not completely disappear in adulthood (Lefly and Pennington 1991). Nonlinear latent growth models showed that a broad reading and writing index had the largest rate of change (faster growth) between ages 2 and 19 years and the second lowest change (slower decline) across the ages 20-75 years compared to other cognitive abilities (McArdle et al. 2002). Variability in acquisition of reading during childhood is influenced by genetic and environmental factors although maximal reading and writing performance is not achieved until the mid-20s (McArdle et al. 2002). Thus, genetic effects which for reading skill increase during development and are mostly stable across time (Hart et al. 2013) might be greatest once this maximal attainment is reached. It may be, then, that the genetic study of reading ability in adults is a more (rather than less) sensitive approach for identifying genes.

Genetic association studies of reading traits have primarily been performed in samples of children, adolescents and young adults, particularly those with dyslexia. A number of candidate genes for reading impairment have been discovered, with successful replications in independent samples (Scerri and Schulte-Koene 2010), including reading measures collected in childhood and adolescent general-population samples (Luciano et al. 2007; Paracchini et al. 2011). We predicted that such candidate genes would show association with reading in older adults. As a starting point we included 11 genes that were recently exon sequenced and systematically tested for association with developmental dyslexia by Matsson and colleagues (2015). Of these, seven-CYP19A1, DCDC2, DYX1C1, GCFC2 (or C2orf3), KIAA0319, MRPL19, and ROBOI-were found by initial linkage evidence which then led to associations with specific genetic variants that were replicated in multiple independent studies (see reviews by Raskind et al. 2012; Scerri and Schulte-Koene 2010). Table 1 indicates the level of existing support for these candidate genes based on positive and null associations between SNPs in these genes and dyslexia/ reading-related measures. The four additional genes-DIP2A, PRMT2, PCNT, and S1OOB - located in a region on 21q22.3 were identified through segregation analysis in a Dutch family with developmental dyslexia (Poelmans et al. 2009). Of these, $S 100 B$ has since received independent support in German families as a developmental dyslexia candidate gene (Matsson et al. 2015). Two further genes-CNTNAP2 and $C M I P-$ were part of a dyslexia candidate gene set tested for replication by Carrion-Castillo et al. (2017) because they had been associated with reading measures in at least two independent samples. Finally, KIAA0319L has been the focus of dyslexia association studies (Couto et al. 2008) and lies in an independently replicated linkage region (Scerri and Schulte-Koene 2010). We thus examined a total of 14 candidate genes.

To test association, we focussed on individual SNPs within these genes previously tested for association with reading dis(ability) and gene-set analysis which included (1) the 14 candidate genes, (2) genes within the axon guidance pathway, and (3) genes within the neuron migration pathway. The axon guidance (GO:0007411: "chemotaxis process that directs the migration of an axon growth cone to a specific target site") and neuron migration (GO:0001764: "movement of an immature neuron from germinal zones to specific positions where they will reside as they mature") pathways are theorised to be prominent biological pathways involved in reading impairment (Poelmans et al. 2011) based on the function of the dyslexia candidate genes.

\section{Materials and methods}

\section{Participants}

\section{The Lothian Birth Cohort of 1936 (LBC1936)}

This cohort, born in 1936, mostly resided in the Edinburgh region of Scotland and consisted of 1091 community dwelling participants (49.8\% women) (Deary et al. 2012, 2004). They were aged approximately 70 years at collection of the cognitive phenotypes used in this study and were relatively healthy at the time of testing; none had dementia. The sample score higher on childhood intelligence and have higher socio-economic status (SES) than the general population (Deary et al. 2012). Blood was obtained by trained nurses to extract DNA for genotyping at the time of their clinical visit. Ethics permission was obtained from the Multi-Centre Research Ethics Committee for Scotland (MREC/01/0/56), the Lothian Research Ethics Committee (LREC/2003/2/29). Written informed consent was given by all participants.

\section{The Lothian Birth Cohort of 1921 (LBC1921)}

This cohort, born in 1921, mostly resided in the Edinburgh region of Scotland and consist of 550 relatively healthy community dwelling participants (57.4\% women) (Deary et al. 2004, 2012). They were aged approximately 79 years at collection of the cognitive phenotypes used in this study; exclusions were made for dementia. Like LBC1936, this sample differed from the general population in childhood intelligence and SES. Blood was obtained by trained nurses to extract DNA for genotyping at the time of their clinical visit. Ethics permission was obtained from the Lothian Research Ethics Committee (LREC/1998/4/183). Written informed consent was given by all participants. 


\section{Genotyping}

DNA, extracted from blood samples, was genotyped on the Illumina 610-Quadv1 whole-genome SNP array (Illumina, San Diego, CA, USA) by the Genetics Core Laboratory at the Wellcome Trust Clinical Research Facility, Western General Hospital, Scotland. Standard genotype quality control procedures were performed, including checks for gender discrepancies, individual relatedness, and non-Caucasian ascent (for more details see, Houlihan et al. 2010). Necessary exclusions resulted in a final sample of 1005 individuals. Population stratification was controlled using the first four factors extracted from a Multidimensional scaling analysis ( $\mathrm{Li}$ and $\mathrm{Yu}$ 2007) of the identity-by-state distance matrix, as previously detailed for these cohorts (Davies et al. 2011). These were used as covariates in the genetic association analyses. Imputation to the $1000 \mathrm{G}$ European reference panel (phase $1 \mathrm{v} 3$ ) was done using Minimac (van Leeuwen et al. 2015). Only SNPs with a minor allele frequency greater than 5\% and with an imputation quality score $\left(\mathrm{r}^{2}\right)$ greater than .30 were retained for analysis.

\section{Measures}

\section{LBC1936}

Two word recognition tests-National Adult Reading Test, NART (Nelson and Willison 1991); Wechsler Test of Adult Reading, WTAR (Corporation 2001)—were administered. Both of these tests require the correct pronunciation of lowfrequency irregular words and therefore scores on both tests are primarily used as estimates of pre-morbid IQ, that is, they are not indexing the functioning of the lexical storage system per se (Coltheart et al. 2001), but also index vocabulary, which is typically larger in people with higher IQs (Dykiert and Deary 2013). To produce a measure of reading skill independent of IQ, we ran a principal components analysis on a battery of tests: a general cognitive ability test (a modified version of the Moray House Test (MHT) no. 12 (Education 1949)) which examined a variety of mental abilities (e.g., reasoning, arithmetic, spatial, verbal); two nonverbal IQ tests (Wechsler Matrix Reasoning, Wechsler Block Design; (Wechsler 1998)); a phonemic verbal fluency test (the summed score of trials requiring production of words starting with the letters $\mathrm{C}, \mathrm{F}$ and L; Lezak 2004); a self-reported measure of book reading frequency (on a five-point scale from "every day or about every day" to "less than once a year/never,"), and NART and WTAR. We selected book reading in preference to other types of reading (e.g., newspaper) because in the National Adult Literacy survey of almost 25,000 adults, it was more predictive of proficient prose and document literacy than other forms of reading content (Smith 1996). Based on the scree plot, two components had eigenvalues greater than 1 ; an orthogonal (varimax) rotation was used to obtain maximal separation of the reading from the general cognitive ability component. The first component, explaining 38\% of variance, was the general cognitive ability factor (loadings above 0.73 on MHT, Matrix Reasoning, and Block Design and loadings of 0.54 for the NART and WTAR). The second component explained $30 \%$ of variance, and assessed reading independent of IQ. Frequency of book reading loaded highly (0.77) on this component, as did the NART $(0.72$ loading) and WTAR (0.73), and, to a lesser extent, verbal fluency (0.51) and MHT (0.44).This indicated that reading ability could be assessed independent of general cognitive ability. Component scores for the reading component were calculated using a regression approach for those participants with complete data and with genotyping, giving a sample of 879 (436 male) with a mean age of 69.5 years $(S D=0.84)$.

A previous magnetic resonance imaging study in this cohort showed that a verbal executive processing factor partly underlies verbal fluency scores and was associated with a major language-related white matter tract (Hoffman et al. 2017). We therefore calculated such an index by obtaining residual scores from the regression of verbal fluency scores on a standardised composite measure of the NART and WTAR (that is, removing word storage variation from the verbal fluency scores to tap executive processing variation related to their access). Missing data resulted in a sample of 1000 (507 male) with genotyping data with a mean age of 69.6 years $(\mathrm{SD}=0.84)$ for this measure. Given that verbal executive processing has not been the focus of previous genetic studies, we treat these analyses as exploratory and their results are shown in the online supporting material.

\section{LBC1921}

Members of this sample had also completed the NART (but not the WTAR), the verbal fluency test, and MHT. In addition, they had completed the Raven's Standard Progressive Matrices (Raven et al. 1977), a measure of general nonverbal reasoning ability. Roughly four years later, a self-reported measure of lifetime reading (books, newspaper, and magazines) and writing was gathered from a retrospective questionnaire. The lifetime reading component extracted from this questionnaire was primarily defined by book reading.

To obtain a measure of reading ability independent of general cognitive ability, a principal components analysis of each of these measures was performed using varimax rotation, with two components retained based on their eigenvalues being greater than 1 . The first component, explaining $48 \%$ of variance, tapped general cognitive ability, loading 0.90 and 0.87 on MHT and Raven's, respectively. As expected, NART and verbal fluency also loaded substantially on this general component with respective loadings of 0.75 and 0.54 , with the rotated component score approach allowing us to control for this 
g-loaded component of the tests. The second orthogonal component, explaining $24 \%$ of shared variance, was defined most strongly by lifetime reading (0.92), NART and verbal fluency (loadings of 0.40), and thus tapped reading skill in this sample. Reading component scores were produced for 365 individuals due to a reduced sample for the lifetime reading component; 338 (138 male) with a mean age of 79.1 years $(\mathrm{SD}=0.56)$ had genetic data. A verbal executive processing index was created from residual scores obtained from the regression of verbal fluency on standardised NART. For this supplementary analysis, scores were available for 503 (208 male) genotyped individuals with a mean age of 79.1 years $(\mathrm{SD}=0.6)$.

\section{Statistical analyses}

Genome-wide SNP association analysis was performed using mach2qtl ( $\mathrm{Li}$ et al. 2009) under an additive model, and controlling for age, gender, and the first four population stratification components. Analyses were conducted separately in the LBC1936 and LBC1921 cohorts and the results meta-analysed using a weighted inverse variance method in METAL (Willer et al. 2010). Genome-wide SNP association results were used to evaluate the over-representation of significant associations in an omnibus test of the 14 candidate genes as a gene set; follow-up analyses were performed for each individual gene. Further, two biological pathways-neuron migration (containing 103 genes) and axon guidance (containing 203 genes) - were tested for overrepresentation of significant associations. Relevant genes in these pathways (defined by respective GO:0001764 and GO:0007411 terms) were downloaded from the gene ontology database, http://amigo.geneontology.org/amigo. Gene set tests (i.e., candidate gene set, neuron migration, axon guidance) were performed in MAGMA (de Leeuw et al. 2015) using a competitive gene-set approach, which, in essence, tests whether there is greater association of SNPs in the specified gene set compared to other genes. By default, MAGMA conditions the gene set on gene size, gene density (relative level of linkage disequilibrium between SNPs) and the inverse of the mean minimum allele count in the gene (to guard against reduced power for those SNPs with low frequency). SNPs within a gene are defined by the transcription start and stop sites of that gene. Because our gene sets overlapped, Bonferroni correction for multiple testing was deemed too conservative. Instead, in MAGMA, we established a family-wise error rate corrected alpha level $(\mathrm{p}<.017)$ empirically using 20,000 permutations-this large number of permutations was needed because the corrected $p$ value was close to the significance level.

The 14 candidate genes contained 9225 SNPs, 62 of which have been previously associated with reading ability/disability (Becker et al. 2014; Carrion-Castillo et al. 2017; Couto et al. 2008; Paracchini et al. 2011; Poelmans et al. 2011), and included variants identified through Fluorescent In Situ Hybridization and SNP microarray analyses of a deletion on 21q22.3 but not specifically tested for association (Table II in, Poelmans et al. 2009). Based on 47.81 independent tests, as determined by the matrix spectral decomposition software which considers marker linkage disequilibrium (Nyholt 2004), replication level support for these single SNPs was judged against a Bonferroni-adjusted $\mathrm{p}$ value of .001 .

\section{Results}

In LBC1936, (standardised) component scores for the reading component were normally distributed with no extreme scores (range: -3.5 to 2.2 ; skew: -.51 ). Individuals with scores less than 2.5 SD from the mean had Mini-Mental State Examination (Folstein et al. 1975) scores above 25 indicating that they were not affected by undiagnosed dementia. In LBC1921, (standardised) component scores for the reading component were normally distributed with no outliers (range: -2.5 to 2.1; skew: -.22 ).

The QQ plot for the reading component (Fig. 1) is shown for all SNPs lying within the dyslexia candidate genes of interest; see online Fig. 1 for verbal executive processing. There is some positive deviation in observed $p$ values from the null distribution, attributable to genetic signal. The genome-wide SNP association results (downloadable from http://www.ccace.ed.ac.uk/) were used in the gene-based tests. Analysed as a broad 'candidate' gene-set, significant SNPs within the 14 candidate genes were overrepresented among our results for the reading component (Standardised Beta $=.014$, Beta $=0.51, \mathrm{SE}=0.24, \mathrm{p}=.016$ ) but not for verbal executive processing $(\mathrm{p}>.05)$. Results for the individual genes within the significant gene set are shown in Table 1.

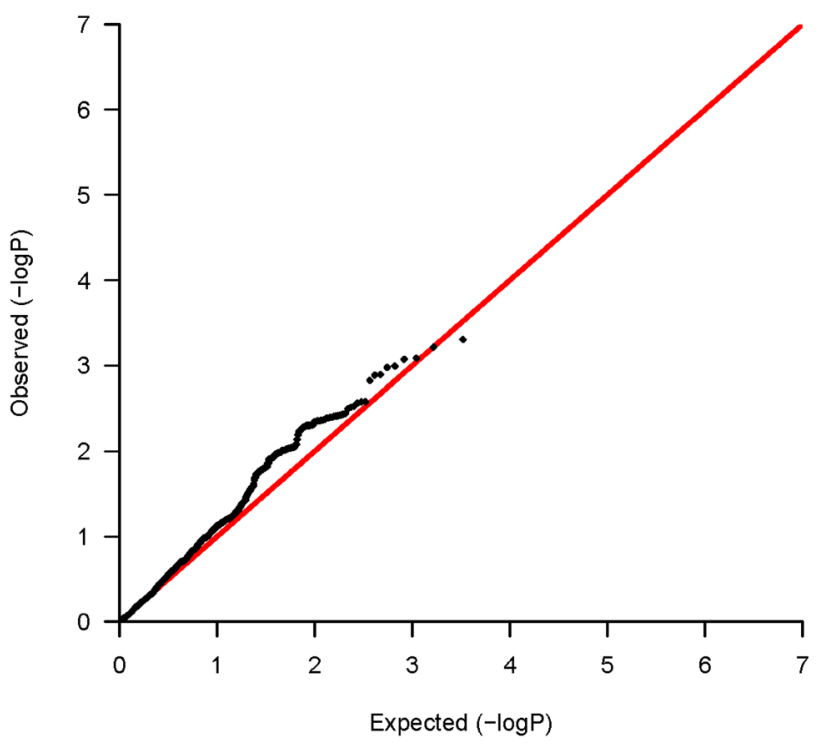

Fig. 1 QQ Plot for dyslexia candidate SNP associations $(\mathrm{N}=9225$ SNPs) with the reading component 


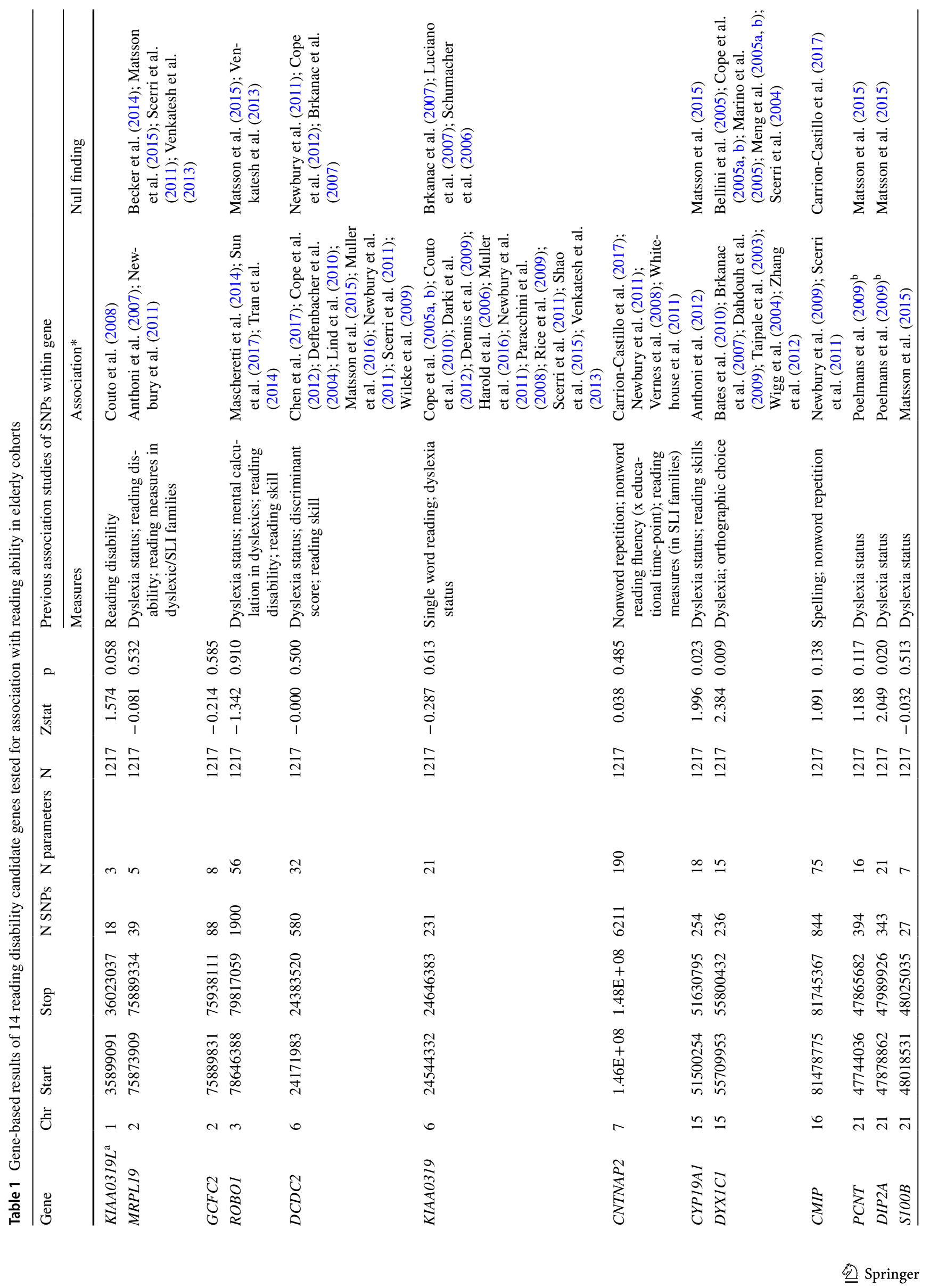


Based on their p-values, it may be that CYP19A1, DYX1C1, $D I P 2 A$, and KIAA0319L contribute more to the overall association between the candidate gene set and reading ability. Gene-set analysis of neuron migration and axon guidance pathways were not significant for the reading component or verbal executive processing $(\mathrm{p}>.05)$.

With regard to individual SNP association we focus on 62 SNPs within the candidate genes previously linked to reading ability/disability. Results for these SNPs are presented in online Table 1 (see online Table 2 for verbal executive processing). None reached the corrected significance level.

\section{Discussion}

The question of whether genetic influences on developmental disorders can be detected in adulthood is an important one because it broadens the sampling frame available to study such traits. Not only did our study replicate genetic effects found for specific reading disorder, but it did so in a sample of older individuals ( $\geq 70$ years) who were not reading impaired. The reading skill index was associated with the 14 candidate gene-set as a whole, with the strongest individual gene support coming from $D Y X 1 C 1, D I P 2 A$, CYP19A1 and KIA00319L. Axon guidance and neuron migration pathways were not significant.

Given that the results of our replication study might be of interest to future meta-analyses in the area, it is important to more closely examine the individual SNP effects despite them attaining only nominal significance. Within $D Y X 1 C 1$, now known as Dynein Axonemal Assembly Factor 4 (DNAAF4), the direction of allelic effect for rs3743204 (the most significant variant) was consistent with Bates et al. (2010), and Becker et al. (2014) who found the minor allele associated with better reading scores in respective population and reading-impaired samples. Our effect for rs7174102 was in the same direction as Paracchini et al. (2011) who, for a population-based sample, reported a negative effect of the minor allele on spelling scores. And in this same sample, reading scores were positively associated with the minor allele of rs8040756, consistent with our findings. For CNTNAP2, rs759178, rs17236239 and rs2710102 have been previously associated with language traits in the general population (Luciano et al. 2013; Whitehouse et al. 2011) and in impairment (also rs4431523, Vernes et al. 2008); our direction of allelic effect for these SNPs was consistent with these studies. Note that Carrion-Castillo et al. (2017) reported the opposite direction of effect for rs 17236239 . None of the nominally significant SNPs in DIP2A have been previously reported in association studies of reading impairment/ability and here we show that they might have effects on verbal executive processing as well as reading ability. The only other gene with suggestive effects on verbal executive 
processing was $R O B O 1$, previously implicated in verbal phonological processing (Bates et al. 2011). Whereas our SNP replication results were only nominally significant, the consistent direction of effect with the majority of previous studies boosts evidence in favour of these effects being true findings. Based on findings for other related complex traits (e.g., general cognitive ability) (Hill et al. 2018), individual SNP effects are likely to be very small ( $<.5 \%$ variance), so our findings align with this framework. It is widely assumed that common learning disabilities represent the low tail of normal abilities in the population, so it is unlikely that our failure to replicate previous dyslexia candidate genes is based on a different genetic aetiology of impaired and normal reading (see, Haworth and Plomin 2010).

DYXICA/DNAAF4 has a purported role in neuronal migration during cerebral cortex development, whereas $D I P 2 A$ has been implicated in axon pathfinding and patterning in the central nervous system (http://www.genecards. org) (Tammimies et al. 2013; Tanaka et al. 2010; Wang et al. 2006; Zhang et al. 2015). Nevertheless, neuron migration and axon guidance pathways (as a whole) were not significantly associated with reading skill in our study. Given the incompleteness of GO terms and annotation bias towards genes that are well-studied (Haynes et al. 2018) we must be cautious to accept these null findings, and these pathways should be interrogated in the future as GO annotation improves, especially the quality of predicted gene function. Because these are only hypothesised biological pathways, the discovery of further genetic variants for reading (dis) ability might show that they are not the primary pathways involved in reading ability/specific learning disorder. Further, other genes might compensate for negative mutations in these pathways and effects of related brain plasticity may potentially differ by age and sex (Galaburda 2005; Galaburda et al. 2006; Poelmans et al. 2011).

CYP19A1 encodes a member of the cytochrome P450 superfamily of enzymes, it is in the same genetic locus as $D Y X 1 C 1$, and appeared to contribute to the signal of the candidate gene-set based on its individual gene association. It has a role in testosterone to $17 \beta$-estradiol conversion, sex differentiation in the brain, and differentiation of specific brain regions in early mammalian development (Anthoni et al. 2012). Elevated levels of testosterone during perinatal development have been argued to contribute to learning disorder via lateralisation effects; oestrogen receptor beta signalling might be key in this process (Varshney and Nalvarte 2017). CYP19A1 expression in human brain is related to expression of DYX1C1: $60 \%$ of variance in expression levels in nine regions of adult brain was shared (Anthoni et al. 2012). It is possible that most of the signal from our positive 14 candidate gene-set association stems from the combined associations for CYP19A1 and
$D Y X 1 C 1$, indicating the importance of the DYX1 locus, one of the most replicated quantitative trait loci for reading disability (Brkanac et al. 2007).

The present study highlights the potential importance that studying adults has for genetic discoveries in the area of developmental disorders, specifically reading impairment. If prenatal and early life developmental processes that affect the brain (and resulting reading ability) are in part genetically influenced then these genetic influences will be detected in adults provided that difficulties in reading acquisition are contiguous with later life ability. Both the phenotypic and genetic literature shows this to be true, with genetic influences on reading processes in the acquisition phases strongly correlated with reading performance later on (Byrne et al. 2009; Hart et al. 2013; Petrill et al. 2007), for example, in the teenage years no new genetic factors come into play (Wadsworth et al. 2001). Here, we are able to show that a candidate gene set of 14 genes that have individually been linked to reading disability, primarily in children and adolescents, are associated with reading ability in older Scottish people. By using adults in large-scale genotyping studies (arguably a more feasible design than in children) we are likely to speed up progress in gene discovery for dyslexia and potentially other learning disorders. It will be imperative, however, to establish what the most sensitive later life measures of early reading difficulties are given that over time individuals will develop strategies to mask their poor reading. The prospect of using nonvocal phonologically based group assessment (Wolff and Lundberg 2003) would be a way to quickly accrue large adult samples.

Acknowledgements We thank the LBC1921 and LBC1936 participants and team members.

Funding The whole genome association study was funded by the Biotechnology and Biological Sciences Research Council (BBSRC) (Ref. BB/F019394/1). The LBC1936 data collection was funded by Research Into Ageing (Ref. 251) and Age UK's Disconnected Mind programme. The LBC1921 data collection was funded by the BBSRC (Ref. 15/SAG09977). The work was undertaken within The University of Edinburgh Centre for Cognitive Ageing and Cognitive Epidemiology, funded by the BBSRC and Medical Research Council (MR/ K026992/1).

\section{Compliance with ethical standards}

Conflict of interest Michelle Luciano, Alan J. Gow, Alison Pattie, Timothy C. Bates, and Ian J. Deary declares that they have no conflict of interest.

Ethical approval All procedures performed in studies involving human participants were in accordance with the ethical standards of the institutional and/or national research committee and with the 1964 Helsinki declaration and its later amendments or comparable ethical standards. 
Informed consent Informed consent was obtained from all individual participants included in the study.

Open Access This article is distributed under the terms of the Creative Commons Attribution 4.0 International License (http://creativeco mmons.org/licenses/by/4.0/), which permits unrestricted use, distribution, and reproduction in any medium, provided you give appropriate credit to the original author(s) and the source, provide a link to the Creative Commons license, and indicate if changes were made.

\section{References}

Anthoni H, Zucchelli M, Matsson H, Muller-Myhsok B, Fransson I, Schumacher J et al (2007) A locus on 2p12 containing the coregulated MRPL19 and C2ORF3 genes is associated to dyslexia. Hum Mol Genet 16(6):667-677

Anthoni H, Sucheston LE, Lewis BA, Tapia-Paez I, Fan XT, Zucchelli $M$ et al (2012) The aromatase gene CYP19A1: several genetic and functional lines of evidence supporting a role in reading, speech and language. Behav Genet 42(4):509-527

Bates TC, Castles A, Coltheart M, Gillespie N, Wright M, Martin NG (2004) Behaviour genetic analyses of reading and spelling: a component processes approach. Aust J Psychol 56(2):115-126

Bates TC, Lind PA, Luciano M, Montgomery GW, Martin NG, Wright MJ (2010) Dyslexia and DYX1C1: deficits in reading and spelling associated with a missense mutation. Mol Psychiatry 15(12):1190-1196

Bates TC, Luciano M, Medland SE, Montgomery GW, Wright MJ, Martin NG (2011) Genetic variance in a component of the language acquisition device: ROBO1 polymorphisms associated with phonological buffer deficits. Behav Genet 41(1):50-57

Becker J, Czamara D, Scerri TS, Ramus F, Csepe V, Talcott JB et al (2014) Genetic analysis of dyslexia candidate genes in the European cross-linguistic NeuroDys cohort. Eur J Hum Genet 22(5):675-680

Bellini G, Bravaccio C, Calamoneri F, Donatella Cocuzza M, Fiorillo P, Gagliano A et al (2005) No evidence for association between dyslexia and DYX1C1 functional variants in a group of children and adolescents from Southern Italy. J Mol Neurosci 27(3):311-314

Brkanac Z, Chapman NH, Matsushita MM, Chun L, Nielsen K, Cochrane E et al (2007) Evaluation of candidate genes for DYX1 and DYX2 in families with dyslexia. Am J Med Genet B 144B(4):556-560

Byrne B, Coventry WL, Olson RK, Samuelsson S, Corley R, Willcutt EG et al (2009) Genetic and environmental influences on aspects of literacy and language in early childhood: continuity and change from preschool to Grade 2. J Neurolinguist 22(3):219-236

Carrion-Castillo A, Maassen B, Franke B, Heister A, Naber M, van der Leij A et al (2017) Association analysis of dyslexia candidate genes in a Dutch longitudinal sample. Eur J Hum Genet 25(4):452-460

Chen Y, Zhao H, Zhang Y-X, Zuo P-X (2017) DCDC2 gene polymorphisms are associated with developmental dyslexia in Chinese Uyghur children. Neural Regen Res 12(2):259-266

Coltheart M, Rastle K, Perry C, Langdon R, Ziegler J (2001) DRC: a dual route cascaded model of visual word recognition and reading aloud. Psychol Rev 108(1):204-256

Cope N, Harold D, Hill G, Moskvina V, Stevenson J, Holmans P et al (2005a) Strong evidence that KIAA0319 on chromosome $6 p$ is a susceptibility gene for developmental dyslexia. Am J Hum Genet 76(4):581-591

Cope NA, Hill G, van den Bree M, Harold D, Moskvina V, Green EK et al (2005b) No support for association between dyslexia susceptibility 1 candidate 1 and developmental dyslexia. Mol Psychiatry 10(3):237-238

Cope N, Eicher JD, Meng H, Gibson CJ, Hager K, Lacadie C et al (2012) Variants in the DYX2 locus are associated with altered brain activation in reading-related brain regions in subjects with reading disability. Neuroimage 63(1):148-156

Corporation TP (2001) Wechsler test of adult reading. The Psychological Corporation, San Antonio

Couto JM, Gomez L, Wigg K, Cate-Carter T, Archibald J, Anderson B et al (2008) The KIAA0319-like (KIAA0319L) gene on chromosome $1 \mathrm{p} 34$ as a candidate for reading disabilities. J Neurogenet 22(4):295-313

Couto JM, Livne-Bar I, Huang K, Xu Z, Cate-Carter T, Feng Y et al (2010) Association of reading disabilities with regions marked by acetylated H3 histones in KIAA0319. Am J Med Genet B 153B(2):447-462

Dahdouh F, Anthoni H, Tapia-Paez I, Peyrard-Janvid M, SchulteKorne G, Warnke A et al (2009) Further evidence for DYX1C1 as a susceptibility factor for dyslexia. Psychiatr Genet 19(2):59-63

Darki F, Peyrard-Janvid M, Matsson H, Kere J, Klingberg T (2012) Three dyslexia susceptibility genes, DYX1C1, DCDC2, and KIAA0319, affect temporo-parietal white matter structure. Biol Psychiatry 72(8):671-676

Davies G, Tenesa A, Payton A, Yang J, Harris SE, Liewald D et al (2011) Genome-wide association studies establish that human intelligence is highly heritable and polygenic. Mol Psychiatry 16:996

de Leeuw CA, Mooij JM, Heskes T, Posthuma D (2015) MAGMA: generalized gene-set analysis of GWAS data. PLoS Comput Biol 11(4):e1004219

Deary IJ, Whalley LJ, Lemmon H, Crawford JR, Starr JM (2000) The Stability of individual differences in mental ability from childhood to old age: follow-up of the 1932 Scottish Mental Survey. Intelligence 28(1):49-55

Deary IJ, Whiteman MC, Starr JM, Whalley LJ, Fox HC (2004) The impact of childhood intelligence on later life: following up the Scottish Mental Surveys of 1932 and 1947. J Pers Soc Psychol 86(1): 130

Deary IJ, Gow AJ, Pattie A, Starr JM (2012) Cohort profile: the lothian birth cohorts of 1921 and 1936. Int J Epidemiol 41(6):1576-1584

Deffenbacher KE, Kenyon JB, Hoover DM, Olson RK, Pennington BF, DeFries JC, Smith SD (2004) Refinement of the 6p21.3 quantitative trait locus influencing dyslexia: linkage and association analyses. Hum Genet 115(2):128-138

Dennis MY, Paracchini S, Scerri TS, Prokunina-Olsson L, Knight JC, Wade-Martins R et al (2009) A common variant associated with dyslexia reduces expression of the KIAA0319 gene. PLoS Genet 5(3): 1000436

Dykiert D, Deary IJ (2013) Retrospective validation of WTAR and NART scores as estimators of prior cognitive ability using the lothian birth cohort 1936. Psychol Assess 25(4):1361-1366

Education SCfRi (1949) The trend of Scottish intelligence. University of London Press, Ltd., London

Fisher SE, DeFries JC (2002) Developmental dyslexia: genetic dissection of a complex cognitive trait. Nat Rev Neurosci 3(10):767-780

Folstein MF, Folstein SE, McHugh PR (1975) "Mini-mental state". A practical method for grading the cognitive state of patients for the clinician. J Psychiatr Res 12(3):189-198

Foorman BR, Breier JI, Fletcher JM (2003) Interventions aimed at improving reading success: an evidence-based approach. Dev Neuropsychol 24(2-3):613-639

Francks C, Paracchini S, Smith SD, Richardson AJ, Scerri TS, Cardon LR et al (2004) A 77-kilobase region of chromosome 6 p22.2 is associated with dyslexia in families from the 
United Kingdom and from the United States. Am J Hum Genet 75(6): 1046-1058

Galaburda AM (2005) Dyslexia-a molecular disorder of neuronal migration. Ann Dyslexia 55(2):151-165

Galaburda AM, LoTurco J, Ramus F, Fitch RH, Rosen GD (2006) From genes to behavior in developmental dyslexia. Nat Neurosci 9(10):1213-1217

Harold D, Paracchini S, Scerri T, Dennis M, Cope N, Hill G et al (2006) Further evidence that the KIAA0319 gene confers susceptibility to developmental dyslexia. Mol Psychiatry 11(12):1085-1091

Hart SA, Logan JAR, Soden-Hensler B, Kershaw S, Taylor J, Schatschneider C (2013) exploring how nature and nurture affect the development of reading: an analysis of the Florida twin project on reading. Dev Psychol 49(10):1971-1981

Haworth CMA, Plomin R (2010) Quantitative genetics in the era of molecular genetics: learning abilities and disabilities as an example. J Am Acad Child Psychiatry 49(8):783-793

Hayiou-Thomas ME, Harlaar N, Dale PS, Plomin R (2010) Preschool speech, language skills, and reading at 7, 9, and 10 years: etiology of the relationship. J Speech Lang Hear Res 53(2):311-332

Haynes WA, Tomczak A, Khatri P (2018) Gene annotation bias impedes biomedical research. Sci Rep 8(1):1362

Hill WD, Marioni RE, Maghzian O, Ritchie SJ, Hagenaars SP, McIntosh AM et al (2018) A combined analysis of genetically correlated traits identifies 187 loci and a role for neurogenesis and myelination in intelligence. Mol Psychiatry 2018:1

Hoffman P, Cox SR, Dykiert D, Muñoz Maniega S, Valdés Hernández MC, Bastin ME et al (2017) Brain grey and white matter predictors of verbal ability traits in older age: the lothian birth cohort 1936. NeuroImage 156:394-402

Houlihan LM, Davies G, Tenesa A, Harris SE, Luciano M, Gow AJ et al (2010) Common variants of large effect in F12, KNG1, and HRG are associated with activated partial thromboplastin time. Am J Hum Genet 86(4):626-631

Lefly DL, Pennington BF (1991) Spelling-errors and reading fluency in compensated adult dyslexics. Ann Dyslexia 41:143-162

Lezak M (2004) Neuropsychological testing. Oxford University Press, Oxford

Li Q, Yu K (2007) Improved correction for population stratification in genome-wide association studies by identifying hidden population structures. Genet Epidemiol 32(3):215-226

Li Y, Willer C, Sanna S, Abecasis G (2009) Genotype imputation. Annu Rev Genomics Human Genet 10:387-406

Lind PA, Luciano M, Wright MJ, Montgomery GW, Martin NG, Bates TC (2010) Dyslexia and DCDC2: normal variation in reading and spelling is associated with DCDC2 polymorphisms in an Australian population sample. Eur J Hum Genet 18(6):668-673

Luciano M, Lind PA, Duffy DL, Castles A, Wright MJ, Montgomery GW et al (2007) A haplotype spanning KIAA0319 and TTRAP is associated with normal variation in reading and spelling ability. Biol Psychiatry 62(7):811-817

Luciano M, Evans DM, Hansell NK, Medland SE, Montgomery GW, Martin NG et al (2013) A genome-wide association study for reading and language abilities in two population cohorts. Genes Brain Behav 12(6):645-652

Luciano M, Hagenaars SP, Cox SR, Hill WD, Davies G, Harris SE et al (2017) Single nucleotide polymorphisms associated with reading ability show connection to socio-economic outcomes. Behav Genet 47(5):pp

Marino C, Giorda R, Luisa Lorusso M, Vanzin L, Salandi N, Nobile $\mathrm{M}$ et al (2005) A family-based association study does not support DYX1C1 on 15q21.3 as a candidate gene in developmental dyslexia. Eur J Hum Genet 13(4):491-499

Mascheretti S, Riva V, Giorda R, Beri S, Lanzoni LFE, Cellino MR, Marino C (2014) KIAA0319 and ROBO1: evidence on association with reading and pleiotropic effects on language and mathematics abilities in developmental dyslexia. J Hum Genet 59(4):189-197

Matsson H, Huss M, Persson H, Einarsdottir E, Tiraboschi E, NopolaHemmi J et al (2015) Polymorphisms in DCDC2 and S100B associate with developmental dyslexia. J Hum Genet 60(7):399-401

McArdle JJ, Ferrer-Caja E, Hamagami F, Woodcock RW (2002) Comparative longitudinal structural analyses of the growth and decline of multiple intellectual abilities over the life span. Dev Psychol 38(1):115-142

Meng H, Hager K, Held M, Page GP, Olson RK, Pennington BF et al (2005a) TDT-association analysis of EKN1 and dyslexia in a Colorado twin cohort. Hum Genet 118(1):87-90

Meng HY, Smith SD, Hager K, Held M, Liu J, Olson RK et al (2005b) DCDC2 is associated with reading disability and modulates neuronal development in the brain. Proc Natl Acad Sci USA 102(47):17053-17058

Muller B, Wilcke A, Czepezauer I, Ahnert P, Boltze J, Kirsten H, consortium L (2016) Association, characterisation and meta-analysis of SNPs linked to general reading ability in a German dyslexia case-control cohort. Sci Rep 6:27901

Nelson HE, Willison J (1991) National adult reading test (NART) test manual. NFER-NELSON Publishing Company Ltd., Windsor

Newbury DF, Winchester L, Addis L, Paracchini S, Buckingham LL, Clark A et al (2009) CMIP and ATP2C2 modulate phonological short-term memory in language impairment. Am J Hum Genet 85(2):264-272

Newbury DF, Paracchini S, Scerri TS, Winchester L, Addis L, Richardson AJ et al (2011) Investigation of dyslexia and SLI risk variants in reading- and language-impaired subjects. Behav Genet 41(1):90-104

Nyholt DR (2004) A simple correction for multiple testing for singlenucleotide polymorphisms in linkage disequilibrium with each other. Am J Hum Genet 74(4):765-769

Paracchini S, Steer CD, Buckingham LL, Morris AP, Ring S, Scerri T et al (2008) Association of the KIAA0319 dyslexia susceptibility gene with reading skills in the general population. Am J Psychiatry 165(12):1576-1584

Paracchini S, Ang QW, Stanley FJ, Monaco AP, Pennell CE, Whitehouse AJ (2011) Analysis of dyslexia candidate genes in the Raine cohort representing the general Australian population. Genes Brain Behav 10(2):158-165

Petrill SA, Deater-Deckard K, Thompson LA, Schatschneider C, Dethorne LS, Vandenbergh DJ (2007) Longitudinal genetic analysis of early reading: the Western reserve reading project. Read Writ 20(1-2):127-146

Poelmans G, Engelen JJM, Van Lent-Albrechts J, Smeets HJ, Schoenmakers E, Franke B et al (2009) Identification of novel dyslexia candidate genes through the analysis of a chromosomal deletion. Am J Med Genet B 150B(1):140-147

Poelmans G, Buitelaar JK, Pauls DL, Franke B (2011) A theoretical molecular network for dyslexia: integrating available genetic findings. Mol Psychiatry 16(4):365-382

Price AL, Spencer CCA, Donnelly P (2015) Progress and promise in understanding the genetic basis of common diseases. Proc R Soc B 282(1821):20151684

Raskind WH, Peter B, Richards T, Eckert MM, Berninger VW (2012) The genetics of reading disabilities: from phenotypes to candidate genes. Front Psychol 3:601

Raven JC, Court JH, Raven J (1977) Manual for raven's progressive matrices and vocabulary scales. H. K. Lewis., London

Rice ML, Smith SD, Gayan J (2009) Convergent genetic linkage and associations to language, speech and reading measures in families of probands with specific language impairment. J Neurodev Disord 1(4):264-282

Scerri TS, Schulte-Koene G (2010) Genetics of developmental dyslexia. Eur Child Adoles Psychiatry 19(3):179-197 
Scerri TS, Fisher SE, Francks C, MacPhie IL, Paracchini S, Richardson AJ et al (2004) Putative functional alleles of DYX1C1 are not associated with dyslexia susceptibility in a large sample of sibling pairs from the UK. J Med Genet 41(11):853-857

Scerri TS, Morris AP, Buckingham LL, Newbury DF, Miller LL, Monaco AP et al (2011) DCDC2, KIAA0319 and CMIP are associated with reading-related traits. Biol Psychiatry 70(3):237-245

Schumacher J, Anthoni H, Dahdouh F, König IR, Hillmer AM, Kluck $\mathrm{N}$ et al (2006) Strong genetic evidence of DCDC2 as a susceptibility gene for dyslexia. Am J Hum Genet 78(1):52-62

Shao S, Kong R, Zou L, Zhong R, Lou J, Zhou J et al (2015) The roles of genes in the neuronal migration and neurite outgrowth network in developmental dyslexia. Single- and multiple-risk genetic variants. Mol Neurobiol 53(6):3967-3975

Smith MC (1993) Change in reading ability and attitudes from childhood to adulthood: a life span perspective. In: Yussen SR, Smith MC (eds) Reading across the life span. Springer, New York, pp 273-291

Smith MC (1996) Differences in adults' reading practices and literacy proficiencies. Read Res Quart 31(2):196-219

Sun X, Song S, Liang X, Xie Y, Zhao C, Zhang Y et al (2017) ROBO1 polymorphisms, callosal connectivity, and reading skills. Hum Brain Mapp 38(5):2616-2626

Taipale M, Kaminen N, Nopola-Hemmi J, Haltia T, Myllyluoma B, Lyytinen $\mathrm{H}$ et al (2003) A candidate gene for developmental dyslexia encodes a nuclear tetratricopeptide repeat domain protein dynamically regulated in brain. Proc Natl Acad Sci USA 100(20):11553-11558

Tammimies K, Vitezic M, Matsson H, Le Guyader S, Bürglin TR, Öhman T et al (2013) Molecular networks of DYX1C1 gene show connection to neuronal migration genes and cytoskeletal proteins. Biol Psychiatry 73(6):583-590

Tanaka M, Murakami K, Ozaki S, Imura Y, Tong XP, Watanabe T et al (2010) DIP2 disco-interacting protein 2 homolog A (Drosophila) is a candidate receptor for follistatin-related protein/ follistatin-like 1 -analysis of their binding with TGF- $\beta$ superfamily proteins. FEBS J 277(20):4278-4289

Tran C, Wigg KG, Zhang K, Cate-Carter TD, Kerr E, Field LL et al (2014) Association of the ROBO1 gene with reading disabilities in a family—based analysis. Genes Brain Behav 13(4):430-438

van Leeuwen EM, Kanterakis A, Deelen P, Kattenberg MV, Genome of the Netherlands C, Slagboom PE et al (2015) Population-specific genotype imputations using minimac or IMPUTE2. Nat Protoc 10(9):1285-1296

Varshney M, Nalvarte I (2017) Genes, gender, environment, and novel functions of estrogen receptor beta in the susceptibility to neurodevelopmental disorders. Brain Sci 7(3):24
Venkatesh SK, Siddaiah A, Padakannaya P, Ramachandra NB (2013a) Lack of association between genetic polymorphisms in ROBO1, MRPL19/C2ORF3 and THEM2 with developmental dyslexia. Gene 529(2):215-219

Venkatesh SK, Siddaiah A, Padakannaya P, Ramachandra NB (2013b) Analysis of genetic variants of dyslexia candidate genes KIAA0319 and DCDC2 in Indian population. J Hum Genet 58(8):531-538

Vernes SC, Newbury DF, Abrahams BS, Winchester L, Nicod J, Groszer M et al (2008) A functional genetic link between distinct developmental language disorders. New Engl J Med 359(22):2337-2345

Wadsworth SJ, Corley RP, Hewitt JK, DeFries JC (2001) Stability of genetic and environmental influences on reading performance at 7 , 12, and 16 years of age in the Colorado Adoption Project. Behav Gene 31(4):353-359

Wang Y, Paramasivam M, Thomas A, Bai J, Kaminen-Ahola N, Kere J et al (2006) DYX1C1 functions in neuronal migration in developing neocortex. Neuroscience 143(2):515-522

Wang K, Li M, Hakonarson H (2010) Analysing biological pathways in genome-wide association studies. Nat Rev Genet 11(12):843-854

Wechsler D (1998) WAIS-III UK administration and scoring manual. Psychological Corporation, London

Whitehouse AJO, Bishop DVM, Ang QW, Pennell CE, Fisher SE (2011) CNTNAP2 variants affect early language development in the general population. Genes Brain Behav 10(4):451-456

Wigg KG, Couto JM, Feng Y, Anderson B, Cate-Carter TD, Macciardi F et al (2004) Support for EKN1 as the susceptibility locus for dyslexia on 15q21. Mol Psychiatry 9(12):1111-1121

Wilcke A, Weissfuss J, Kirsten H, Wolfram G, Boltze J, Ahnert P (2009) The role of gene DCDC2 in German dyslexics. Ann Dyslexia 59(1):1-11

Willer CJ, Li Y, Abecasis GR (2010) METAL: fast and efficient meta-analysis of genomewide association scans. Bioinformatics 26(17):2190-2191

Wolff U, Lundberg I (2003) A technique for group screening of dyslexia among adults. Ann Dyslexia 53(1):324-339

Zhang Y, Li J, Tardif T, Burmeister M, Villafuerte SM, McBrideChang C et al (2012) Association of the DYX1C1 dyslexia susceptibility gene with orthography in the chinese population. PLoS ONE 7(9):e42969

Zhang L, Mabwi HA, Palange NJ, Jia R, Ma J, Bah FB et al (2015) Expression patterns and potential biological roles of Dip2a. PLoS ONE 10(11):e0143284 